femme ... semble peu favorable aux changements mêmes ceux dont elle ne pourrait que retiret des avantages ... il faut encore avoir le personnel voulu pour entreprendre la tâche d'atteindre le milieu féminin. ... Il n'existe malheureusement pas en Oubangui de jeune fille noire capable d'un tel travail. . . .' Un travail de quatre mois à Boykota et dans la région permettait d'arriver à quelques conclusions : l'éducation de base répond à un besoin et à un désir des populations africaines; des résultats ne sont atteints que lorsque des liens de confiance et de sympathie ont pu être établis entre les éduqués et les éducateurs; on peut espérer que les indigènes foutniront spontanément l'effort nécessaire à leur propre évolution, mais pas rapidement. Le rythme de vie d'un village africain n'est pas bouleversé par la présence d'une equipe d'éducation de base.

[Abrégé d'un article de Jean Chalvet, Nouvelle Revue Frangais d'outre-mer, juillet-août I954.]

\title{
Centre d'études de linguistique bantoue (Brazzaville)
}

Le cours de langues africaines fondé par M. Eliet le 26 juin I954 a tenu plusieurs séances pendant lesquelles les questions traitées ont été: la structure du bantou, le concept du temps/espace, le verbe 'être', les langues véhiculaires, les emprunts des langues étrangers et les méthodes de leur intégration en bantou. Une conférence a été prononcée par M. Edmond Nzenza Nlandu, rédacteur du mensuel belge Kongo Dia Ngunga, au sujet de l'unification de la langue kikongo.

\section{Soil Conservation}

A REPORT on land erosion in non-self-governing territories ${ }^{1}$ was prepared by the United Nations secretariat for review by the Committee on Information from non-self-governing territories. The report indicates that these territories are specially susceptible to soil erosion and soil exhaustion, as the result of various factors : climate, excessive stock-keeping, bushburning, faulty drainage, \&c. Since soil conservation is bound up with improved farming and proper land use, comprehensive planning for whole agricultural areas is required, and this may involve sweeping social and economic changes. Successful area plans require co-operative efforts between individual farmers and community action under the guidance of government agencies. The report contains information on measures taken in territories administered by Belgium, France, the United Kingdom, and the United States.

\section{Malaria Control}

As a result of a resolution adopted by the I95 I Malaria conference convened at Kampala by the World Health Organization, the Nigerian Malaria service initiated and planned the Malaria Control Project in Gwandu Emirate, Sokoto Province, Northern Nigeria. A series of preliminary surveys led to the selection of Gwandu Emirate, where the disease carried by mosquitoes, which are extremely numerous in that area, causes severe suffering among infants and children. The project in its initial phase covers 600 square miles and will protect a population of $\mathrm{x} 20,000$. Several spraying squads will move from village to village by special vehicles, spraying houses, stables, cattle-sheds, chicken coops, \&c. twice a year. A team of doctors and other specialists will travel all over the country and, using mobile laboratories, will study the progress of the project by assessing the numbers of mosquitoes still alive, and also the improvement in health of the population.

The cost of the project is being borne as to one half by the Northern Regional Government; grants have been received from the International Children's Fund, while the World Health Organization and the Colonial Insecticide Research Committee are contributing by providing specialists.

\footnotetext{
I Soil Conservation, Doc. A/AC. 35/L. I6o.
} 